\title{
Spatial Spillover Effects of Environmental Regulations on China's Haze Pollution Based on Static and Dynamic Spatial Panel Data Models
}

\author{
Xuemin Liu' ${ }^{1}$ Li Li ${ }^{1 *}$, Jiaoju Ge', Dengli Tang², Shuqi Zhao ${ }^{3}$ \\ ${ }^{1}$ School of Economics and Management, Harbin Institute of Technology, Shenzhen, China \\ ${ }^{2}$ School of Business Administration, Guangdong University of Finance and Economics, Guangzhou, China \\ ${ }^{3}$ Finance and Public Management Institute, Harbin University of Commerce, Harbin, China
}

Received: 30 March 2018

Accepted: 6 May 2018

\begin{abstract}
Rapid industrialization and urbanization have presented a dilemma to traditional environmental policies, and severe haze pollution has attracted particular attention in China. This paper employed the exploratory spatial data analysis technique to analyze global and local spatial auto-correlation of environmental regulations (ERS) and haze pollution. Static and dynamic spatial panel data models were further established to investigate the influence of ERS and its spatial spillover effect on haze pollution across 31 provinces of China in 2005-2015. Results showed that significant spatial autocorrelation existed for both ERS and haze pollution in China, forming different aggregation regions in terms of geographical distribution. There was strong evidence for the "inverted-U"-shaped EKC relationship between ERS and haze pollution regardless of whether it was the static or dynamic spatial econometric model. In addition, haze pollution was not only affected by economic growth, population size, and urbanization, but also by the haze pollution in the previous period. Conclusions and control strategies that would be of great significance for implementing effective management measures were synoptically discussed.
\end{abstract}

Keywords: environment regulations, spatial effect, haze pollution, spatial econometric models

\section{Introduction}

The haze pollution in China is becoming increasingly serious, especially in mega cities with highly populated clusters [1]. In 2016 about 254 out of 338 cites could not meet the National Ambient Air Quality Standards of China, accounting for $75.1 \%$. The population-weighted average of $\mathrm{PM}_{2.5}$ in China's cities reached $61 \mu \mathrm{g} / \mathrm{m}^{3}$

*e-mail: ximlli@126.com
- up to 3 times as high as the global mean [2]. These figures not only reflect the grim situation, but also indicate the limited capacity of the government to address the haze pollution. Haze refers to especial weather characterized by horizontal visibility of less than $10 \mathrm{~km}$ caused by the light extinction of particulate matter [3]. In general, transport emissions [4], industrial exhausts [5], municipal heating [6], biomass burning [7], seasonal variability [8], and regional aerosols [9] are major contributors to haze pollution, but quantifying each source remains challenging due to different chemical characteristics in various regions. For example, 
nitrate played a more dominant role than sulfate in the Yangtze River Delta region, which is different from the North China Plain region [10]. A range of scholars have conducted extensive research on the formation mechanisms of haze pollution [8, 11-13], but the process is too complex to simulate its dynamic evolution. Basically, anomalous meteorological conditions such as low wind speed, high humidity, and large-scale atmospheric circulations play a very important role in causing haze pollution [5, 14], which could elevate concentrations of aerosols and its chemical components during haze days [4].

In addition, plants, regarded as the source of life in nature (whether forests, landscapes, or houseplants) perform indispensable ecological functions in maintaining human living environments. Species most resistant to water stress, such as Pinus nigra and Cupressus sempervirens, are particularly necessary for water shortages areas [15]. Although no experiments have yet demonstrated that plants could absorb particulate matter, they indeed consume carbon dioxide and sulfur dioxide, and reduce airborne dust to indirectly prevent the formation of haze pollution [16]. However, the function of plants to improve air quality is limited by climatic and edaphic conditions, referring to nutriment elements, enzyme activity, and effective hormones [17, 18] - in short, bioclimatic comfort and appropriate soil structure are essential for the life of living things [19]. It can be seen that haze pollution is definitely not only caused by a single factor, but also is one of the consequences of the maladjustment of the natural ecosystem.

Despite a certain degree of plant, soil, meteorological, and geographical factors, the socioeconomic drivers including rapid industrialization, urbanization, economic growth, population aggregation, transportation, and inefficient ERS are culprits from the perspective of economics and management disciplines [13]. Take transportation as an example, on the one hand, exhaust emissions are closely related to haze pollution, on the other hand, heavy metals arising from car wheels and vehicle corrosion tend to bioaccumulate, which weaken the function of plants to purify the air [20]. With the intensification of environmental pollution, various studies regarding ERS have been conducted, like its connotation, type, legislation, heterogeneity, efficiency, and effect [21-24]. ERS can generally be divided into the command-and-control type (non-market based) and the motivate-and-cooperate type (market-based) [21], but their impacts on firm specific behaviors are sometimes quite different [25]. One other thing that needs to be emphasized is that ERS builds the foundation of the three major environmental theories. The pollution haven hypothesis believes that pollution-intensive corporations prefer countries with looser ERS to avoid strict ERS in their own countries [26]. The race-to-thebottom hypothesis emphasizes that developing countries compete to reduce their ERS standards in order to attract more foreign-funded enterprises [27]. The porter hypothesis maintains that appropriate ERS can stimulate enterprises to carry out technological innovation, thus ensuring and enhancing the competitiveness of enterprises [28]. It can be found that ERS plays a decisive role in the theoretical basis of environmental protection, even though large numbers of models such as the slacks-based measure model [21, 22, 29], spatial Durbin model [23, 30], and structural equation model [25] are widely used in existing literatures. With regard to empirical studies, the relationship between ERS and the total factor/green productivity [22], energy efficiency [29], foreign direct investment [31, 32], firm/government competitiveness [25, 33], and technological innovation [34] have been explored. For example, Decai Tang et al. (2017) found there was a significant "match-up" effect between ERS and economic development level [22]. Bin $\mathrm{Li}$ and Shusheng $\mathrm{Wu}$ (2017) investigated the influences of both local and civil ERS on green total factor productivity, concluding that ERS inhibited the original technological innovation of enterprises [23]. However, Xiaoli Zhao et al. (2015) showed that ERS enhanced firm competitiveness by promoting the firm behavior shift toward green development [25], because ERS had significant positive effects in terms of clean production industries [35]. In addition, conclusions like tougher ERS leading to less foreign direct investment [32] and ERS affecting energy efficiency in China's thermal power generation [29] have also been put forward.

Overall, the relative low efficiency of ERS in China, coupled with the haze's cross-border nature and spillover characteristics, makes it harder to manage. However, the examples of "APEC Blue" and "Olympic Blue" have fully demonstrated that ERS is effective during a special period, and that embodying the control of haze pollution depends largely on the intensity, supervision, and execution of ERS. Above discussions and results have important implications for the development of this study, but there are still some deficiencies. First, researches of haze pollution mainly focus on the fields of environment, meteorology, chemistry, and ecology, while there is still a lack of systematic research on the causes and mechanisms from the perspective of economic management. Second, the effects of ERS on technological progress, local government competition, and environmental pollution have been widely studied, while its specific impact on haze pollution is largely ignored. Third, although the traditional panel data analysis is often applied, to the best of our knowledge, research on ERS and haze pollution based on the spatial econometric analysis has not yet appeared. Fourth, even if the spatial econometric method has never been introduced (like the Durbin model), the majorities of them are static rather than dynamic.

In view of this, the purpose of this research is to:

1. Taking ERS and haze pollution as research objects, thoroughly investigate the spatial spillover effects of ERS on haze pollution using exploratory spatial data analysis (ESDA). 
Table 1. Summary of abbreviations in the text.

\begin{tabular}{|c|c|c|c|c|c|}
\hline No. & Abbr. & Full name & No. & Abbr. & Full name \\
\hline 1 & ERS & Environmental regulations & 12 & SLM & Space lag model \\
\hline 2 & ESDA & Exploratory spatial data analysis & 13 & SEM & Spatial error model \\
\hline 3 & EKC & Environmental Kuznets curve & 14 & CIAM & Comprehensive Index Assessment Method \\
\hline 4 & APEC & Asia-Pacific Economic Cooperation & 15 & FEM & Fixed effect model \\
\hline 5 & FDI & Foreign direct investment & 16 & REM & Random Effect Model \\
\hline 6 & R\&D & Research and development & 17 & LM-Lag & Lagrange multiplier lag \\
\hline 7 & GSA & Global spatial auto-correlation & 18 & LM-Error & Lagrange multiplier error \\
\hline 8 & LSA & Local spatial auto-correlation & 19 & SFE & Space fixed effect \\
\hline 9 & MSP & Moran scatter plot & 20 & TFE & Time fixed effect \\
\hline 10 & LISA & Local indicator of spatial association & 21 & STFE & Space-time dual fixed effect \\
\hline 11 & OLS & Ordinary least squares & & & \\
\hline
\end{tabular}

2. Constructing static and dynamic spatial panel data models based on the environmental Kuznets Curve while considering the time lag, space lag, and timespace lag effects.

3. Examining the effects of seven socioeconomic drivers on haze pollution, including economic growth, FDI, industrial structure, population density, urbanization process, transportation, and R\&D intensity.

Abbreviations used in this paper are summarized and explained in Table 1.

\section{Methods}

\section{Exploratory Spatial Data Analysis (ESDA)}

In order to analyze spatial spillover effects on haze pollution, the technology of ESDA is needed [36], including global spatial auto-correlation (GSA) and local spatial auto-correlation (LSA).

GSA is usually applied to describe spatial distribution characteristics in the entire study area and is measured by the indices of global Moran's I, as:

global Moran's $I=\left[\sum_{i=1}^{n} \sum_{j=1}^{n} w_{i j}\left(x_{i}-\bar{x}\right)\left(x_{j}-\bar{x}\right)\right] /\left[S^{2} \sum_{i=1}^{n} \sum_{j=1}^{n} w_{i j}\right]$

where, $\quad S^{2}=\frac{1}{n} \sum_{i=1}^{n}\left(x_{i}-\bar{x}\right)^{2} ; \quad \bar{x}=\frac{1}{n} \sum_{i=1}^{n} x_{i}$

...where Moran's $I$ values between -1 and 1 reflect the degree of similarity of attribute values of each neighboring spatial regions, $n$ presents the 31 provinces and regions in China, $x_{i}$ and $x_{j}$ are observed annual averaged $\mathrm{PM}_{10}$ concentrations from regions $i$ and $j, w_{i}$ is a spatial weight matrix, $\bar{x}$ is the average observed variables, and $S^{2}$ is the corresponding variance. Standardize Moran's I as:

$$
\begin{gathered}
Z(I)=\frac{\operatorname{Moran}^{\prime} S I-E(I)}{\sqrt{\operatorname{VAR}(I)}}, \text { where } E(I)=-\frac{1}{n-1}, \operatorname{VAR}(I)=\frac{n^{2} w_{1}+n w_{2}+3 w_{0}^{2}}{w_{0}^{2}\left(n^{2}-1\right)}-E^{2}(I), \\
w_{0}=\sum_{i=1}^{n} \sum_{j=1}^{n} w_{i j}, w_{1}=\frac{1}{2} \sum_{i=1}^{n} \sum_{j=1}^{n}\left(w_{i j}+w_{j i}\right)^{2}, w_{2}=\sum_{i=1}^{n} \sum_{j=1}^{n}\left(w_{i g}+w_{g j}\right)^{2}
\end{gathered}
$$

LSA is used for evaluating spatial agglomeration, spatial heterogeneity or spatial regimes among regions, measured by Moran scatter plot (MSP) and local indicator of spatial association (LISA). Local Moran's I is expressed as:

local Moran' $I_{i}=\frac{\left(x_{i}-\bar{x}\right)_{0}}{S^{2}}{ }_{j=1}^{n} w_{i j}\left(x_{j}-\bar{x}\right)$

...where $x_{i}, x_{j}, n, w_{i j}$, and $S^{2}$ are the same as calculating global Moran's I index.

In this study, a spatial-adjacency-relationship-based spatial weight matrix is introduced, where $w_{i j}=1$ if region $i$ and $j$ are adjacent cells; otherwise, $w_{i j}=0 . w_{i j}$ is calculated as follows:

$$
w_{i j}=\left[\begin{array}{cccc}
w_{11} & w_{12} & \mathrm{~K} & w_{1 n} \\
w_{21} & w_{22} & \mathrm{~K} & w_{2 n} \\
\mathrm{M} & \mathrm{M} & \mathrm{M} & \mathrm{M} \\
w_{n 1} & w_{n 2} & \mathrm{~K} & w_{n n}
\end{array}\right]
$$

\section{Model Specification}

Grossman and Krueger (1995) found an inverted U-shaped relationship between economic development and pollution emissions - the so-called environmental Kuznets curve (EKC) [37]. ERS has direct and indirect effects on environmental quality, and there may be a non-monotonic relationship between them [38]. Meanwhile, all variables are logarithmically processed in order to eliminate heteroscedasticity. According to 
the general equilibrium model of Antweiler et al. (2001) [39] and EKC, the basic model is constructed as below:

$$
\begin{aligned}
\ln P_{i t} & =\alpha_{0}+\alpha_{1} \ln G D P_{i t}+\alpha_{2} \ln ^{2} G D P_{i t} \\
& +\alpha_{3} \ln E R S_{i t}+\alpha_{4} \ln E R S_{i t}^{2}+\alpha_{5} \ln X_{i t}+\varepsilon_{i t}, \quad \varepsilon_{i t} \sim N\left(0, \sigma_{i t}^{2}\right)
\end{aligned}
$$

...where $P_{i t}$ indicates the annual average value of $P M_{10}$, $G D P_{i t}$ represents the output level, ERS $S_{i t}$ shows the intensity of environmental regulations, and $X_{i t}$ reflects other control variables (including FDI, industrial structure, population size, urbanization, transportation, and technical progress). However, when spatial autocorrelation exists, the ordinary least squares (OLS) estimation would lead to invalid results. Thus two different spatial econometrics models are set up based on Anselin's research [34]. The space lag model (SLM) focuses on the spatial diffusion of each variable while the spatial error model (SEM) examines the error impact of the dependent variables. SLM and SEM are described as follows:

$$
\begin{aligned}
& \ln P_{i t}=\rho W \ln P_{i t}+\alpha_{0}+\alpha_{1} \ln G D P_{i t}+\alpha_{2} \ln ^{2} G D P_{i t} \\
& \quad+\alpha_{3} \ln E R S_{i t}+\alpha_{4} \ln ^{2} E R S+\alpha_{5} X_{i t}+\varepsilon_{i t}, \varepsilon_{i t} \sim N\left(0, \sigma_{i t}^{2}\right)
\end{aligned}
$$

$$
\begin{aligned}
\ln P_{i t}=\alpha_{0}+ & \alpha_{1} \ln G D P_{i t}+\alpha_{2} \ln ^{2} G D P_{i t}+\alpha_{3} \ln E R S_{i t} \\
& +\alpha_{4} \ln ^{2} E R S_{i t}+\alpha_{5} X_{i t}+\varepsilon_{i t} \\
\varepsilon_{i t} & =\lambda W \varepsilon+\mu_{i t}, \quad \mu_{i t} \sim N\left(0, \sigma_{i t}^{2}\right)
\end{aligned}
$$

...where $W \ln P_{i t}$ indicates the space lag variable, $\rho$ means the spatial spillover effect with values ranging from -1 to 1 , and $\lambda$ is the spatial autocorrelation coefficient. Considering characteristics of dynamic and continuous changes of environmental pollution, the dynamic spatial panel data model is necessary. Therefore, the lag term of haze pollution $\beta \ln P_{i, t-1}$ is introduced in Eqs. (6) and (7), respectively, as:

$$
\begin{aligned}
& \ln P_{i t}=\beta \ln P_{i, t-1}+\rho W_{i j} \ln P_{i t}+\alpha_{0}+\alpha_{1} \ln G D P_{i t}+\alpha_{2} \ln ^{2} G D P_{i t} \\
& \quad+\alpha_{3} \ln E R S_{i t}+\alpha_{4} \ln ^{2} E R S+\alpha_{5} X_{i t}+\varepsilon_{i t}, \quad \varepsilon_{i t} \sim N\left(0, \sigma_{i t}^{2}\right)
\end{aligned}
$$

$$
\begin{gathered}
\ln P_{i t}=\beta \ln P_{i, t-1}+\alpha_{0}+\alpha_{1} \ln G D P_{i t}+\alpha_{2} \ln ^{2} G D P_{i t} \\
+\alpha_{3} \ln E R S_{i t}+\alpha_{4} \ln ^{2} E R S_{i t}+\alpha_{5} X_{i t}+\varepsilon_{i t} \\
\varepsilon_{i t}=\lambda W \varepsilon_{i t}+\mu_{i t}, \quad \mu_{i t} \sim N\left(0, \sigma_{i t}^{2}\right)
\end{gathered}
$$

\section{Data Sources}

We collected panel data of 31 provinces in China during 2005-2015. All the original economic and regulated data were taken from the National Statistical Yearbook (2006-2016) and China Statistical Yearbook for Regional Economy (2006-2016). It needs to be emphasized that the $\mathrm{PM}_{2.5}$ data was not monitored by cities in China until 2012. Therefore, the annual average of $\mathrm{PM}_{10}$ is used to measure haze pollution in this study. However, the statistics on $\mathrm{PM}_{10}$ in the National Statistical Yearbook are for the provincial capital. Taking into account the spatial spillover effect of the haze pollution and the center status of provincial capital, the $\mathrm{PM}_{10}$ average value of the provincial capital is applied instead of the entire province.

As for ERS, its measurement has always been challenging due to large numbers of data missing and unavailable in the field of haze pollution. In order to accurately reflect the intensity of ERS across various regions of China, the comprehensive index assessment method (CIAM) is introduced to estimate ERS rather than the single indicator, which can only reflect a certain aspect of it. The system of CIAM consists of one target layer (ERS composite index), three evaluation index layers (industrial wastewater, waste gas and solid waste, collectively referred to as "three wastes"), and five single indicator layers including the attainment rate of industrial wastewater, the removal rate of $\mathrm{SO}_{2}$ (smoke, dust), and the comprehensive utilization of solid waste. The calculation steps are as follows:

Firstly, standardize individual indicators:

$$
U E_{i j}^{s}=\left[U E_{i j}-\min \left(U E_{j}\right) /\left[\max \left(U E_{j}\right)-\min \left(U E_{j}\right)\right]\right.
$$

...where $U E_{i j}$ is the original value of the indicator in terms of major pollutant $j$ in all regions and $U E_{i t}{ }^{S}$ is its normalized value.

Secondly, calculate the adjustment factor of each evaluation index. Due to the differences in the nature and attributes of the industry, the proportion of pollution emissions relating to "three wastes" appears differently. The role of the adjustment factor $C_{j}$ is similar to the weight, approximately reflecting the changes in the governance of major pollutants in each region, as:

$$
C_{j}=\frac{E_{i j}}{\sum_{i=1}^{m} E_{i j}} / \frac{P_{i}}{\sum_{i=1}^{m} P_{i}}=\frac{E_{i j}}{P_{i}} / \frac{\sum_{i=1}^{m} E_{i j}}{\sum_{i=1}^{m} P_{i}}=U E_{i j} / \overline{U E_{i j}}
$$

...where $E_{i j}$ represents the emission of pollutant $j$ in $i$ industry and $\sum_{i=1}^{m} E_{i j}$ is the total amount of similar pollutants in the country. $P_{i}$ denotes the output value

of industry $i$ and $\sum_{i=1}^{m} P_{i}$ is its corresponding entire industrial output value. Through identity transformation,

$C_{j}$ is concluded as the ratio of $U E_{i j}$ (unit $E_{i j}$ ) and $\overline{U E_{i j}}$ (national average unit $E_{i j}$ ). 
Table 2. Variables definition and descriptive statistical results.

\begin{tabular}{|c|c|c|c|c|}
\hline Variables & Mean & S.D. & Max & Min \\
\hline $\ln P M_{10}$ & 4.5747 & 0.3177 & 5.7203 & 3.5264 \\
\hline $\ln E R S$ & -1.1135 & 1.5725 & 1.0895 & -5.8091 \\
\hline $\ln ^{2} E R S$ & 3.7056 & 7.8005 & 33.7461 & 0.0005 \\
\hline $\ln G D P$ & 10.1320 & 0.6376 & 11.8702 & 8.5407 \\
\hline $\ln ^{2} G D P$ & 103.0630 & 13.0712 & 140.9022 & 72.9438 \\
\hline $\ln F D I$ & 4.8298 & 1.7606 & 7.4894 & -0.1054 \\
\hline $\ln I S$ & 3.8333 & 0.2072 & 4.1187 & 2.9826 \\
\hline $\ln P S$ & 8.0877 & 0.8560 & 9.2918 & 5.6359 \\
\hline $\ln U D$ & 3.8882 & 0.2891 & 4.4954 & 3.0374 \\
\hline $\ln T R A$ & 8.6598 & 0.9295 & 9.9496 & 5.8749 \\
\hline $\ln R \& D$ & 10.6651 & 1.3565 & 13.1622 & 6.3953 \\
\hline
\end{tabular}

Finally, measure the environmental regulation of each single index $S_{i}$, and then estimate the comprehensive index of ERS, as:

$$
\begin{gathered}
S_{i}=\frac{1}{n} \sum_{j=1}^{n} C_{j} \times U E_{i j}^{S} \\
E R S=\sum_{i=1}^{n} S_{i}
\end{gathered}
$$

Definitions and descriptive statistics of variables are listed in Table 2.

\section{Results and Discussion}

\section{Global Spatial Autocorrelation Analysis}

GeoDa 1.12 software was used to calculate the global Moran's $I$ values of ERS and haze pollution, and their significance levels were tested (Table 3). Both the Moran's $I$ values from 2005 to 2015 were greater than 0 , where the former was between 0.1104 and 0.2145 while the latter varies from 0.1390 to 0.4651 . Meanwhile, both of them passed the significant level test of 0.01 or 0.05 and showed the evolution trend of volatility. This indicates that there is a significant positive spatial correlation for both ERS and haze pollution in China. Their spatial distribution is not random but shows spatial aggregation in some areas, that is, high ERS areas are surrounded by high ERS areas and vice versa.

\section{Local Spatial Autocorrelation Analysis}

Limited to space, the four years of 2006, 2009, 2012, and 2015 were selected as the representative year for further analysis. As shown in Figs 1 and 2 that ERS in most provinces in China was distributed evenly in
Table 3. Moran's $I$ values of ERS in China from 2005 to 2015.

\begin{tabular}{|c|c|c|c|c|}
\hline \multirow{2}{*}{ Year } & \multicolumn{2}{|c|}{ ERS } & \multicolumn{2}{c|}{ Haze pollution } \\
\cline { 2 - 5 } & Moran's $I$ & $P$-value & Moran's $I$ & $P$-value \\
\hline 2005 & 0.2135 & 0.016 & 0.1946 & 0.031 \\
\hline 2006 & 0.2145 & 0.017 & 0.2544 & 0.017 \\
\hline 2007 & 0.2070 & 0.017 & 0.1878 & 0.037 \\
\hline 2008 & 0.1899 & 0.021 & 0.1390 & 0.073 \\
\hline 2009 & 0.1802 & 0.025 & 0.2385 & 0.016 \\
\hline 2010 & 0.1713 & 0.030 & 0.2049 & 0.031 \\
\hline 2011 & 0.1772 & 0.036 & 0.1753 & 0.051 \\
\hline 2012 & 0.1685 & 0.040 & 0.2008 & 0.027 \\
\hline 2013 & 0.1618 & 0.040 & 0.3208 & 0.002 \\
\hline 2014 & 0.1104 & 0.094 & 0.4528 & 0.001 \\
\hline 2015 & 0.1823 & 0.034 & 0.4651 & 0.001 \\
\hline
\end{tabular}

the first three quadrants where the number was close to 10 or so. However, the number of provinces located in the fourth quadrant was as small as 1, 1, 2, and 4, respectively. As for haze pollution, most provinces were located in the first quadrants that include 13, 15, 13, and 15 , respectively. Overall, the total number of hazecontaminated provinces located in the first and third quadrants accounted for $67.74 \%, 74.19 \%, 67.74 \%$, and $80.65 \%$ of the total, respectively. It is further confirmed that there is significant spatial autocorrelation in both ERS and haze pollution.

From Fig. 3, in the local spatial distribution, the ERS in our country has formed different high-valued aggregation regions. In 2006 the ERS high-value gathering area was centered on Hebei, and it was composed of four provinces, including Shanxi, Shaanxi, and Inner Mongolia. After a sharp drop in 2009 (only a province of Shanxi left), the high-high aggregation type has experienced a rebound trend year after year. Inner Mongolia and Shaanxi joined this region in 2012 and 2015, respectively. The ERS located in this concentrated area had a higher intensity and drove the increase of ERS levels in the adjacent areas through cooperation with neighboring regions.

Similarly, as can be seen from Fig. 4, haze pollution in China also formed different aggregation areas in the local spatial distribution, and the spatial aggregation features became more and more obvious with the passage of time. The most prominent were the changes of high-high concentration regions and lowlow agglomeration areas. From the initial high-hazepolluted areas centered on Gansu-Shaanxi in 2006, the trend gradually expanded to the west (Qinghai) and then to the east (Shanxi, Hebei) and north (Inner Mongolia). Until 2015, a total of 6 provinces were in these highhigh aggregation regions covering Shaanxi, Shanxi, Hebei, Henan, Inner Mongolia, and Shandong. Among 


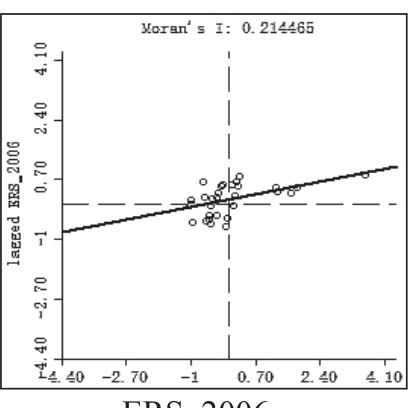

ERS 2006

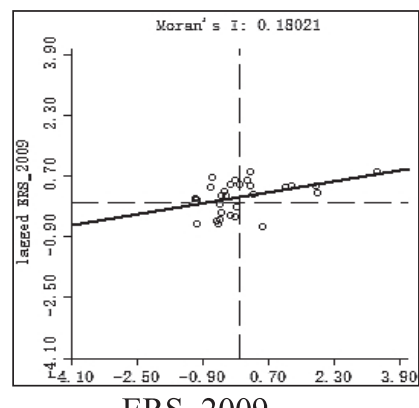

ERS 2009

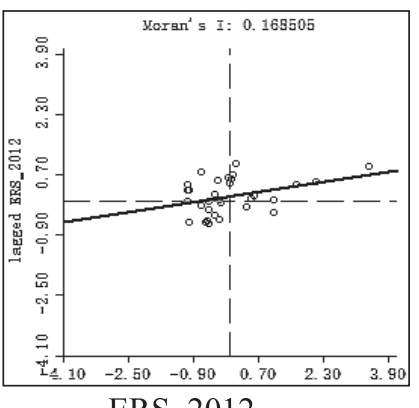

ERS 2012

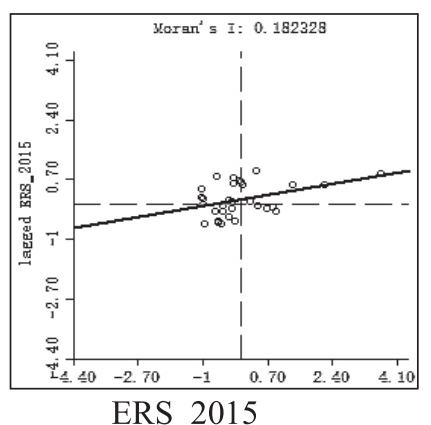

ERS 2015

Fig. 1. Moran scatterplots of ERS in China.
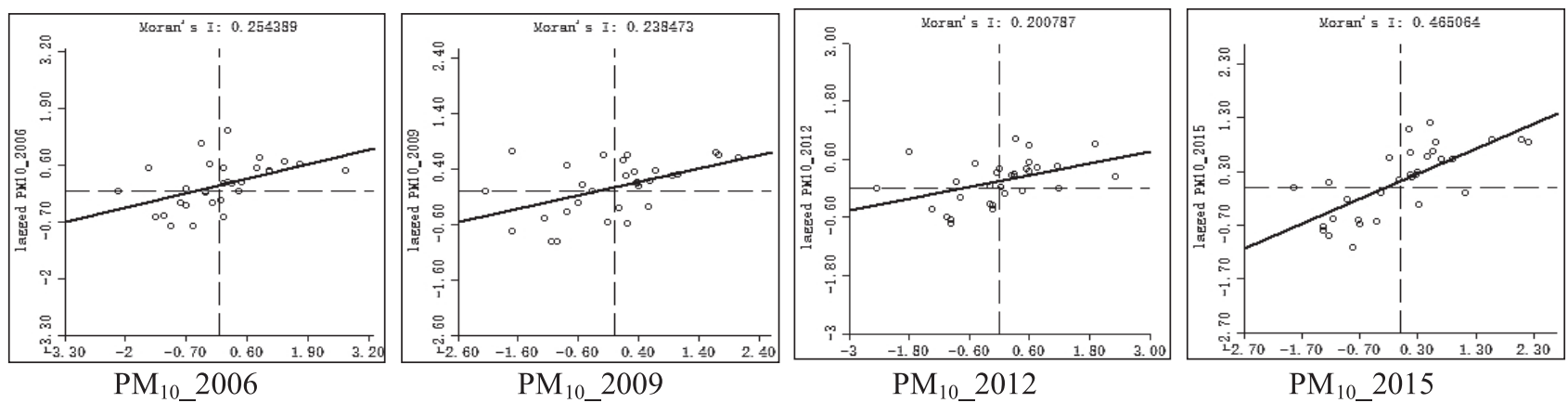

Fig. 2. Moran scatterplots of haze pollution in China.

them, Gansu Province was gradually farther away from high-high gathering areas. The low-haze-polluted areas were centered on Yunnan-Guangdong in 2006, and then gradually extended to neighboring Guangxi and north. Finally, they formed low-low areas with surrounding Guizhou, Yunnan, Jiangxi, and Zhejiang in 2015. In addition, the haze pollution also formed lowhigh agglomeration areas, where the degree of haze
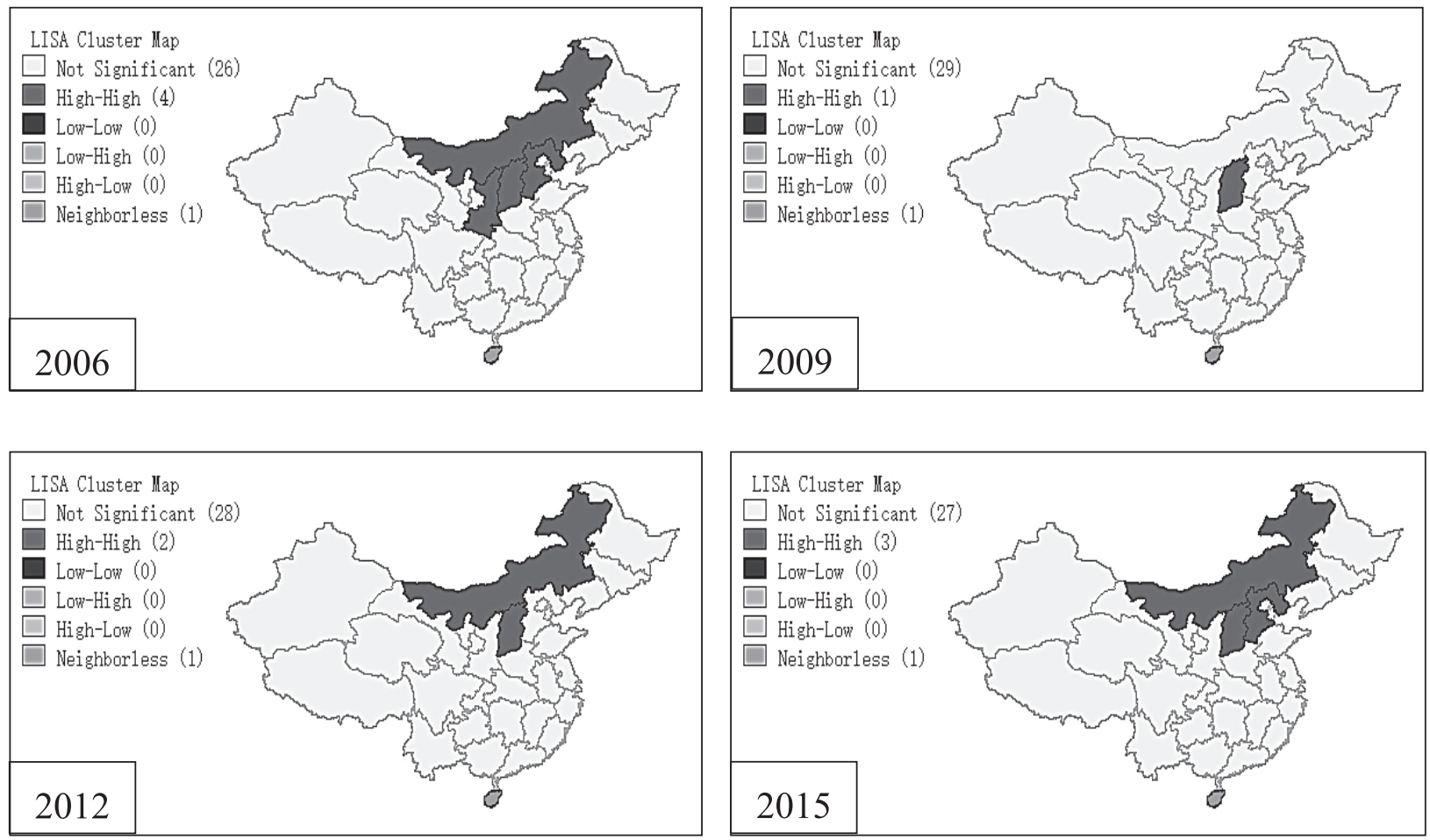

Fig. 3. LISA cluster maps of ERS in China. 

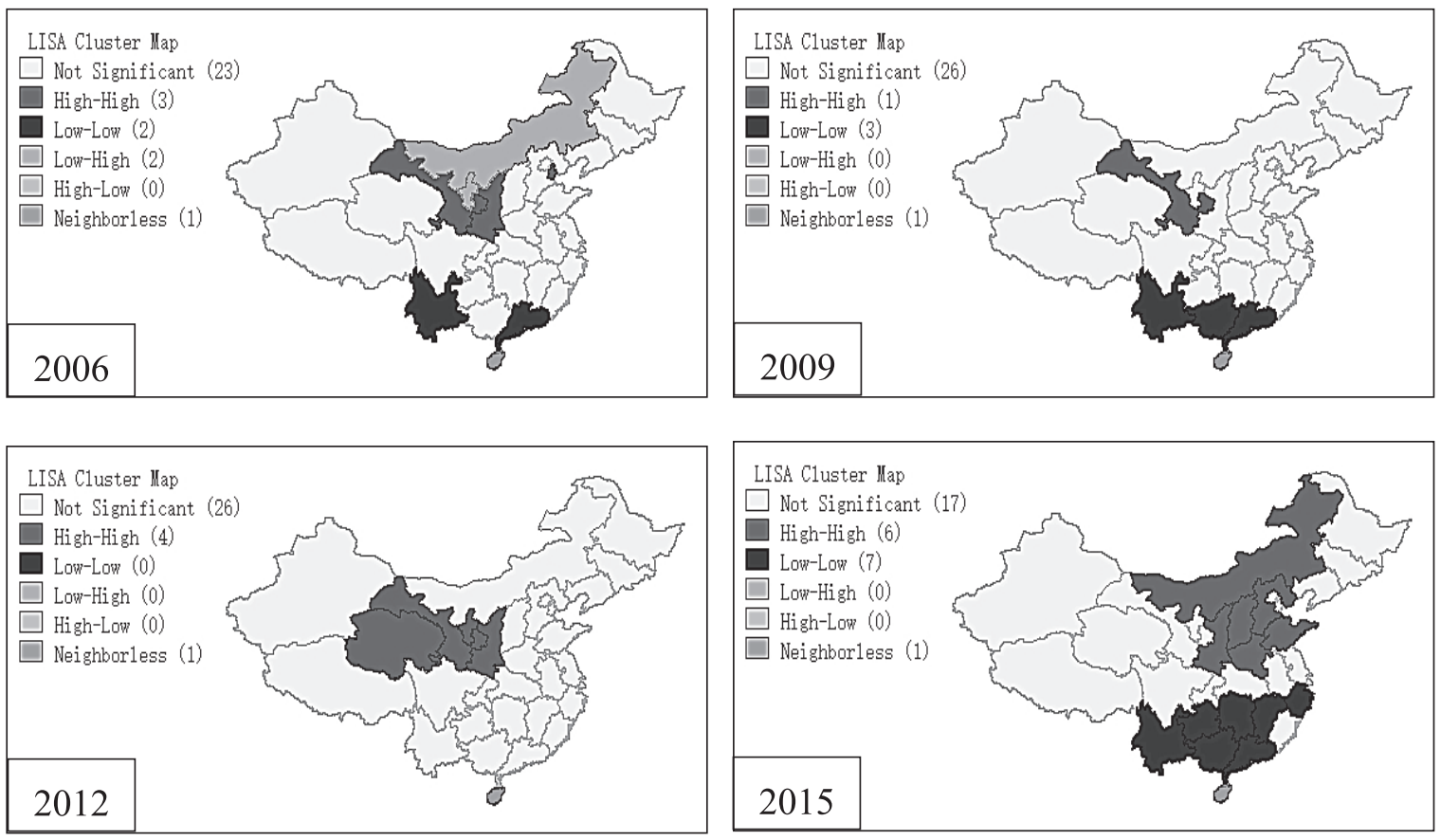

Fig. 4. LISA cluster maps of haze pollution in China.

pollution in Inner Mongolia and Ningxia was low, while the surrounding Gansu and Shaanxi were relatively high, resulting in the initial low-high agglomeration approaching the high-high concentrations. Thus, the level of haze pollution in an area is not only related to its own geographical location, but also related to the degree of haze pollution in the surrounding areas.

\section{Spatial Correlation Test and Model Checking}

From the test results in Table 4, Moran's $I$ values of the two types of models are 0.498 and 0.452 respectively, which are significant at the level of 0.01 , indicating that the haze pollution in China presents spatial autocorrelation. In addition, before conducting spatial econometric analysis, two issues need to be solved.

First, selecting the fixed effect model (FEM) or random effect model (REM) in spatial panel data models: FEM emphasizes that variables containing effects of individuals are endogenous, while REM believes they are exogenous. The difference between them is that the latter ignores the correlation between individual effects and explanatory variables. The statistic of Hausman test was $-58.886(P=0.000)$, indicating that the null hypothesis was rejected at a significance level of 0.01 , which also meant FEM performance was superior to REM in this study.

Second, identifying the spatial lag and spatial errors in panel data models: In the static model, values of the Lagrange multiplier lag (LM-Lag) and Lagrange multiplier error (LM-Error) are 167.554 and 166.423, respectively, which are both significant at the $1 \%$ level. However, the Robust LM-Lag value $(5.605, P=0.018$ ) is larger than the Robust LM-Error value (4.473, $P=0.034$ ), indicating that the spatial lag model is more appropriate. In the same way, for the dynamic model, the spatial lag model is still suitable (see Table 4).

\section{Test of Static Spatial Panel Data Model}

The fixed effects model can be divided into space fixed effect model (SFE), time fixed effect model

Table 4. Static (dynamic) autocorrelation test.

\begin{tabular}{|c|c|c|c|c|}
\hline Test & \multicolumn{2}{|c|}{ Static spatial autocorrelation test } & \multicolumn{2}{c|}{ Dynamic spatial autocorrelation test } \\
\hline & Statistics & $P$ value & Statistics & $P$ value \\
\hline Moran's $I$ & 0.498 & 0.000 & 0.452 & 0.000 \\
\hline LM-Lag & 167.554 & 0.000 & 146.226 & 0.000 \\
\hline Robust LM-Lag & 5.605 & 0.018 & 15.261 & 0.000 \\
\hline LM-Error & 166.423 & 0.000 & 136.942 & 0.000 \\
\hline Robust LM-Error & 4.473 & 0.034 & 5.977 & 0.014 \\
\hline
\end{tabular}


Table 5. Results of static spatial panel data model estimation.

\begin{tabular}{|c|c|c|c|c|c|c|}
\hline \multirow[b]{2}{*}{ Variables } & \multicolumn{3}{|c|}{ Spatial Lag Model } & \multicolumn{3}{|c|}{ Spatial Error Model } \\
\hline & SFE & TFE & STFE & SFE & TPFE & STPFE \\
\hline $\ln E R S$ & $\begin{array}{c}0.0118 \\
(0.2536)\end{array}$ & $\begin{array}{c}-0.0027 \\
(-0.1391)\end{array}$ & $\begin{array}{c}0.0370 \\
(0.8097)\end{array}$ & $\begin{array}{c}-0.0078 \\
(-0.1662)\end{array}$ & $\begin{array}{c}-0.0286 \\
(-1.3640)\end{array}$ & $\begin{array}{c}0.0204 \\
(0.4436)\end{array}$ \\
\hline $\ln ^{2} E R S$ & $\begin{array}{c}-0.0591 * * * \\
(-3.8972)\end{array}$ & $\begin{array}{c}-0.0106^{* *} \\
(-2.1120)\end{array}$ & $\begin{array}{c}-0.0450 * * * \\
(-3.0042)\end{array}$ & $\begin{array}{c}-0.0581 * * * \\
(-4.3239)\end{array}$ & $\begin{array}{c}-0.0159 * * * \\
(-3.1791)\end{array}$ & $\begin{array}{c}-0.0473 * * * \\
(-3.3061)\end{array}$ \\
\hline $\ln G D P$ & $\begin{array}{c}-2.7154 * * * \\
(-4.3055)\end{array}$ & $\begin{array}{l}1.0053 * * \\
(2.0782)\end{array}$ & $\begin{array}{c}-2.2856^{* * *} \\
(-3.1770)\end{array}$ & $\begin{array}{c}-2.4667 * * * \\
(-3.7359)\end{array}$ & $\begin{array}{l}1.1247 * * \\
(2.4095)\end{array}$ & $\begin{array}{c}-2.3174 * * * \\
(-3.0687)\end{array}$ \\
\hline $\ln ^{2} G D P$ & $\begin{array}{c}0.1319^{* * *} \\
(4.3361)\end{array}$ & $\begin{array}{c}-0.0496 * * \\
(-2.2047)\end{array}$ & $\begin{array}{c}0.1182^{* * *} \\
(3.6880)\end{array}$ & $\begin{array}{c}0.1237 * * * \\
(3.8740)\end{array}$ & $\begin{array}{c}-0.0584 * * * \\
(-2.6252)\end{array}$ & $\begin{array}{c}0.1185^{* * *} * \\
(3.5600)\end{array}$ \\
\hline $\ln F D I$ & $\begin{array}{c}-0.0205 \\
(-1.1394)\end{array}$ & $\begin{array}{c}-0.0900 * * * \\
(-5.6069)\end{array}$ & $\begin{array}{c}-0.0111 \\
(-0.6345)\end{array}$ & $\begin{array}{c}-0.0250 \\
(-1.4755)\end{array}$ & $\begin{array}{c}-0.0623 * * * \\
(-4.6670)\end{array}$ & $\begin{array}{c}-0.0158 \\
(-0.9326)\end{array}$ \\
\hline $\ln I S$ & $\begin{array}{c}0.2246^{* *} \\
(2.3396)\end{array}$ & $\begin{array}{c}0.0517 \\
(0.5170)\end{array}$ & $\begin{array}{c}0.1049 \\
(0.8869)\end{array}$ & $\begin{array}{c}0.2108 * * \\
(2.2802)\end{array}$ & $\begin{array}{c}0.0100 \\
(-0.1257)\end{array}$ & $\begin{array}{c}0.1373 \\
(1.2050)\end{array}$ \\
\hline $\ln P S$ & $\begin{array}{l}-0.5434 * \\
(-1.8689)\end{array}$ & $\begin{array}{c}-0.0580 \\
(-1.0589)\end{array}$ & $\begin{array}{c}-0.6243^{* *} \\
(-2.1815)\end{array}$ & $\begin{array}{c}-0.8751^{* *} \\
(-2.5450)\end{array}$ & $\begin{array}{c}-0.0260 \\
(-0.5167)\end{array}$ & $\begin{array}{c}-0.7612^{* *} \\
(-2.4406)\end{array}$ \\
\hline $\ln U D$ & $\begin{array}{c}0.6574 * * * \\
(2.8629)\end{array}$ & $\begin{array}{c}-0.0236 \\
(-0.1686)\end{array}$ & $\begin{array}{c}0.5827 * * \\
(2.4360)\end{array}$ & $\begin{array}{c}0.5394 * * \\
(2.0467)\end{array}$ & $\begin{array}{c}0.0163 \\
(0.1207)\end{array}$ & $\begin{array}{c}0.5314^{* *} \\
(2.1228)\end{array}$ \\
\hline $\ln T R A$ & $\begin{array}{c}-0.0156 \\
(-0.3700)\end{array}$ & $\begin{array}{c}-0.0596 * * * \\
(-3.0018)\end{array}$ & $\begin{array}{c}-0.0504 \\
(-0.7654)\end{array}$ & $\begin{array}{c}-0.0468 \\
(-0.7591)\end{array}$ & $\begin{array}{c}-0.0057 \\
(-0.2342)\end{array}$ & $\begin{array}{c}-0.0502 \\
(-0.7430)\end{array}$ \\
\hline $\operatorname{Ln} R \& D$ & $\begin{array}{c}-0.0209 \\
(-0.5525)\end{array}$ & $\begin{array}{c}0.2254 * * * \\
(7.5193)\end{array}$ & $\begin{array}{c}-0.0235 \\
(-0.5973)\end{array}$ & $\begin{array}{c}-0.0293 \\
(-0.6470)\end{array}$ & $\begin{array}{c}0.1686^{* * *} \\
(5.9037)\end{array}$ & $\begin{array}{c}-0.0279 \\
(-0.6664)\end{array}$ \\
\hline$\rho$ & $\begin{array}{c}0.5250^{* * *} \\
(10.1103) \\
\end{array}$ & $\begin{array}{c}0.6820 * * * \\
(18.7094)\end{array}$ & $\begin{array}{c}0.2680^{* * *} \\
(4.0604)\end{array}$ & $\begin{array}{c}0.5650^{* * *} \\
(11.1493)\end{array}$ & $\begin{array}{c}0.7910^{* * *} \\
(25.3059)\end{array}$ & $\begin{array}{c}0.2990 * * * \\
(4.5354)\end{array}$ \\
\hline$R^{2}$ & 0.8802 & 0.7008 & 0.8892 & 0.8160 & 0.3610 & 0.8808 \\
\hline
\end{tabular}

Note: $* * * * *$ and $*$ indicate the significance at $1 \%, 5 \%$ and $10 \%$ level, respectively. Figs in parentheses are t-statistics

(TFE), and space-time dual fixed effect model (STFE). Tables 5 and 6 show that, regardless of the static model or the dynamic model, the $R^{2}$ value of the STFE is obviously greater than that of the other two models. Therefore, the spatial-time dual fixed effect of the spatial lag panel data model can better explain the influence of ERS on haze pollution under static and dynamic conditions.

From Table 5 we can draw the following conclusions:

First, geographical proximity has a significant positive impact on haze pollution in China, that is, there is a spatial correlation between haze pollution in the region and haze pollution in adjacent areas. The spacetime lag coefficient $\rho$ of the spatial lag panel data model is 0.2680 , which is significant at the level of 0.01 . When the degree of haze pollution in the area increases by $1 \%$, the haze pollution in the neighboring regions will also increase by $0.2680 \%$, indicating that there is a spatial aggregation phenomenon and strong spatial spillover effect of haze pollution. Some scholars have shown that atmospheric circulation, wind direction, rainfall, etc., can affect haze pollution. Due to the long-distance transportation and transfer of pollutants caused by these natural and geographical reasons, haze pollution in an area must be affected by neighboring regions. In addition, transportation, FDI, ERS, etc., will further deepen the spatial correlation of haze pollution between regions. It can be seen that natural spatial and manmade factors are important reasons for the formation of fog and haze pollution. Cross-regional coordination is an effective way to fundamentally resolve regional haze pollution problems [40].

Second, ERS and haze pollution show an inverted U-shaped relationship, indicating that a EKC curve exists between them. Both the STFE of SLM and SEM and the impact coefficient of ERS on haze pollution is positive, while its square term is significantly negative at the level of 0.01 , indicating that there is a threshold value for the influence of ERS on haze pollution. When the ERS intensity is less than the threshold, haze contamination is not improved with ERS enhancement, but haze pollution decreases with increasing ERS intensity when above the threshold. There may be two reasons for this. On one hand, at the initial stage of ERS, China's environmental administrative control, pollution supervision, and economic regulation are all incomplete in that China's economy is in an extensive development stage, that is, at the expense of the environment in exchange for economic development, so haze pollution has not been effectively controlled with the strengthening of the ERS. On the other hand, at the later stage of ERS, the requirements for advanced 
Table 6. Results of dynamic spatial panel data model estimation.

\begin{tabular}{|c|c|c|c|c|c|c|}
\hline \multirow[b]{2}{*}{ Variables } & \multicolumn{3}{|c|}{ Spatial Lag Model } & \multicolumn{3}{|c|}{ Spatial Error Model } \\
\hline & SFE & TPFE & STPFE & SFE & TPFE & STPFE \\
\hline $\ln P_{t-1}$ & $\begin{array}{c}0.1528 * * * \\
(4.8884)\end{array}$ & $\begin{array}{c}0.5019^{* * *} \\
(15.2540)\end{array}$ & $\begin{array}{c}0.2022^{* * *} * \\
(6.2911)\end{array}$ & $\begin{array}{c}0.1929^{* * *} \\
(5.3789)\end{array}$ & $\begin{array}{c}0.5454 * * * \\
(14.5049)\end{array}$ & $\begin{array}{c}0.2087 * * * \\
(6.2161)\end{array}$ \\
\hline $\ln E R S$ & $\begin{array}{c}0.0054 \\
(0.1192)\end{array}$ & $\begin{array}{c}-0.0143 \\
(-0.9058)\end{array}$ & $\begin{array}{c}0.0189 \\
(0.4339)\end{array}$ & $\begin{array}{c}-0.0031 \\
(-0.0696)\end{array}$ & $\begin{array}{c}-0.0126 \\
(-0.7252)\end{array}$ & $\begin{array}{c}0.0130 \\
(0.2978)\end{array}$ \\
\hline $\ln ^{2} E R S$ & $\begin{array}{c}-0.0529 * * * \\
(-3.5829)\end{array}$ & $\begin{array}{c}-0.0097 * * \\
(-2.4131)\end{array}$ & $\begin{array}{c}-0.0379 * * * \\
(-2.6560)\end{array}$ & $\begin{array}{c}-0.0457 * * * \\
(-3.4910)\end{array}$ & $\begin{array}{c}-0.0083^{* *} \\
(-1.9656)\end{array}$ & $\begin{array}{c}-0.0367 * * * \\
(-2.6720)\end{array}$ \\
\hline $\ln G D P$ & $\begin{array}{c}-2.0610 * * * \\
(-3.2950)\end{array}$ & $\begin{array}{l}0.7099^{*} \\
(1.8513)\end{array}$ & $\begin{array}{c}-1.6614^{* *} \\
(-2.4032)\end{array}$ & $\begin{array}{c}-1.9330 * * * \\
(-3.0144)\end{array}$ & $\begin{array}{l}0.7686^{*} \\
(1.9285)\end{array}$ & $\begin{array}{c}-1.7628 * * \\
(-2.4507)\end{array}$ \\
\hline $\ln ^{2} G D P$ & $\begin{array}{c}0.1017 * * * \\
(3.3770)\end{array}$ & $\begin{array}{l}-0.0340^{*} \\
(-1.9086)\end{array}$ & $\begin{array}{c}0.0905^{* * *} \\
(2.9404)\end{array}$ & $\begin{array}{c}0.1005^{* * *} \\
(3.2474)\end{array}$ & $\begin{array}{c}-0.0379^{* *} \\
(-2.0101)\end{array}$ & $\begin{array}{c}0.0944 * * * \\
(2.9744)\end{array}$ \\
\hline $\ln F D I$ & $\begin{array}{c}-0.0139 \\
(-0.7978)\end{array}$ & $\begin{array}{c}-0.0465^{* * *} * \\
(-3.5693)\end{array}$ & $\begin{array}{c}-0.0045 \\
(-0.2730)\end{array}$ & $\begin{array}{c}-0.0147 \\
(-0.8963)\end{array}$ & $\begin{array}{c}-0.0382 * * * \\
(-3.1890)\end{array}$ & $\begin{array}{c}-0.0066 \\
(-0.4086)\end{array}$ \\
\hline $\ln I S$ & $\begin{array}{c}0.2559 * * * \\
(2.7388)\end{array}$ & $\begin{array}{c}0.0068 \\
(0.0849)\end{array}$ & $\begin{array}{c}0.0881 \\
(0.7853)\end{array}$ & $\begin{array}{c}0.2106^{* *} \\
(2.3737)\end{array}$ & $\begin{array}{c}0.0621 \\
(0.8785)\end{array}$ & $\begin{array}{c}0.1142 \\
(1.0491)\end{array}$ \\
\hline $\ln P S$ & $\begin{array}{l}-0.4878^{*} \\
(-1.7266)\end{array}$ & $\begin{array}{c}-0.0519 \\
(-1.1790)\end{array}$ & $\begin{array}{c}-0.6531 * * \\
(-2.3976)\end{array}$ & $\begin{array}{c}-0.8956^{* * *} \\
(-2.7117)\end{array}$ & $\begin{array}{c}-0.0621 \\
(-1.4281)\end{array}$ & $\begin{array}{c}-0.7905^{* * *} \\
(-2.7013)\end{array}$ \\
\hline $\ln U D$ & $\begin{array}{c}0.3723 \\
(1.6201)\end{array}$ & $\begin{array}{c}-0.1051 \\
(-0.9441)\end{array}$ & $\begin{array}{c}0.3295 \\
(1.4292)\end{array}$ & $\begin{array}{c}0.3278 \\
(1.2800)\end{array}$ & $\begin{array}{c}-0.0743 \\
(-0.6402)\end{array}$ & $\begin{array}{c}0.3082 \\
(1.2882)\end{array}$ \\
\hline $\ln T R A$ & $\begin{array}{c}-0.0376 \\
(-0.9150)\end{array}$ & $\begin{array}{c}-0.0371^{* *} \\
(-2.3406)\end{array}$ & $\begin{array}{c}-0.1421 * * \\
(-2.2158)\end{array}$ & $\begin{array}{c}-0.0850 \\
(-1.4232)\end{array}$ & $\begin{array}{c}-0.0085 \\
(-0.4547)\end{array}$ & $\begin{array}{c}-0.1318^{* *} \\
(-2.0169)\end{array}$ \\
\hline$L n R \& D$ & $\begin{array}{c}0.0075 \\
(0.2033)\end{array}$ & $\begin{array}{c}0.1325^{* * *} \\
(5.3167)\end{array}$ & $\begin{array}{c}-0.0039 \\
(-0.1028)\end{array}$ & $\begin{array}{c}-0.0285 \\
(-0.6563)\end{array}$ & $\begin{array}{c}0.1160 * * * \\
(4.5752)\end{array}$ & $\begin{array}{c}-0.0166 \\
(-0.4203)\end{array}$ \\
\hline$\rho$ & $\begin{array}{c}0.5110^{* * *} \\
(9.9015) \\
\end{array}$ & $\begin{array}{c}0.4669 * * * \\
(10.7717) \\
\end{array}$ & $\begin{array}{c}0.2189 * * * \\
(3.3025) \\
\end{array}$ & $\begin{array}{c}0.5680 * * * \\
(11.2558) \\
\end{array}$ & $\begin{array}{c}0.5840^{* * *} \\
(11.8422) \\
\end{array}$ & $\begin{array}{c}0.2590 * * * \\
(3.8276)\end{array}$ \\
\hline$R^{2}$ & 0.8878 & 0.8118 & 0.9002 & 0.8307 & 0.7261 & 0.8949 \\
\hline
\end{tabular}

Note: $* * *, * *$ and $*$ indicate the significance at $1 \%, 5 \%$ and $10 \%$ level, respectively. Figs in parentheses are t-statistics.

production technologies and clean technologies have been gradually increased with the strengthening of ERS. The environmental quality of the region has been improved through technological innovation.

Third, based on the results of spatial econometric tests, the influence of other control variables on haze pollution in China is further analyzed. Research shows that the primary and quadratic coefficients of economic growth are significantly negative and positive respectively at the 0.01 level, indicating that economic development is in a U-shaped relationship with haze pollution. The regression coefficient of population size is -0.6243 , which is significant at the level of $5 \%$. This means that haze pollution can be aggravated with the expansion of population size. The urbanization coefficient of development is 0.5827 , which is significant at the $5 \%$ level, indicating that the rapid expansion of cities has increased haze pollution. However, there is no significant relationship between FDI, industrial structure, transportation, and technological innovation and smog pollution in China. The regression coefficient of the population size is -0.6243 , which is significant at the level of $5 \%$, which shows that haze pollution can be aggravated with population expansion. Moreover, the coefficient of urbanization is 0.5827 , which is significant at the level of $5 \%$, indicating that rapid urbanization expansion aggravates haze pollution. However, FDI, industrial structure, transportation, and technological innovation do not have a significant relationship with haze pollution in China.

\section{Testing the Dynamic Spatial Panel Data Model}

The regression coefficient of the first-phase variable ln $P_{t-1}$, a variable of haze pollution lagging behind, was significantly positive (see Table 6), indicating that the current haze pollution was indeed affected by the haze pollution of the previous period. The space-time lag coefficient $\rho$ is positive and passes a $1 \%$ significance level test, indicating that there is a spatial correlation and spatial spillover effect on haze pollution in adjacent areas. Both regression coefficients of ERS are significant at the $1 \%$ level with estimated values being positive and negative, indicating that in the dynamic spatial panel data model, the ERS and haze pollution still remain in an inverted U-shaped relationship. The impact of economic development level and population size on haze pollution is consistent with the conclusion in the 
static spatial panel data model. The difference is that urbanization development did not pass the significance level test in the dynamic model. However, the regression coefficient of transportation (-0.1421) is significant at the level of $5 \%$, which is contrary to the expected result. The choice of transportation indicators is subject to discussion.

\section{Conclusions}

The exploratory spatial data analysis technique was used in this study to analyze the spatial correlation of ERS and haze pollution in China. The impact of ERS on haze pollution was empirically tested with static and dynamic spatial econometric panel data models, respectively. The panel data of 31 provinces in China was collected. The following main conclusions and policies are obtained and inspired the following.

First of all, the strong spatial autocorrelation significantly existed in both ERS and haze pollution in China, resulted in forming different aggregation areas in geographical distribution, respectively. This showed that haze-polluted areas tend to cluster toward the same type of regions and vice versa. Moreover, the heavily hazecontaminated accumulation area partially overlapped with the ERS high-value aggregated region and expanded to the periphery. Obviously, the influence of space factors on haze pollution cannot be ignored. It is difficult to fundamentally solve the problem of regional haze pollution with their own governance models. To achieve the coordinated development of economy, society, and environmental protection, all regions should break through the regional restrictions on environmental governance and establish a "cross-regional cooperation of joint prevention and control" mechanism for interregional haze pollution.

Secondly, there is strong evidence for the invertedU-shaped EKC relationship between environmental regulations and haze pollution in both static and dynamic spatial econometric models. This shows that in the early stage of implementing environmental regulations, haze pollution in China did not decrease with the strengthening of unilateral environmental control. However, with economic, social, and legislative developments to a certain extent, haze pollution was effectively improved with the increasing intensity of environmental regulations. When formulating a haze pollution control plan, it is necessary to consider the integrated level of development combined with localities, that is, the effectiveness of ERS largely depends on the maturity and sophistication of social comprehensive development rather than its own strength. Therefore, in addition to cross-regional cooperation, the joint development of various functional departments in the region is also a top priority.

Thirdly, haze pollution is not only affected by economic growth, population size, and urbanization. What is more important is that the haze pollution in the current period is indeed affected by previous haze pollution. This indicates that the haze pollution in China is a process of dynamic and gradual accumulation with a certain lag. Its governance is a long-term and arduous task that cannot be accomplished overnight and requires the joint efforts of various stakeholders.

\section{Acknowledgements}

This study was supported by The National Social Science Fund of China (No. 17BJL041).

\section{Conflict of Interest}

The authors declare no conflict of interest.

\section{References}

1. CHAN C.K., YAO X. Air pollution in mega cities in China. Atmospheric Environment, 42 (1), 1, 2008.

2. ZHANG Y., CAO F. Fine particulate matter (PM2.5) in China at a city level. Scientific Reports, 5, 14884, 2015.

3. TANG D., LI L., YANG Y. Spatial econometric model analysis of foreign direct investment and haze pollution in China. Polish Journal of Environmental Studies, 25 (1), 317, 2016.

4. GAO J., TIAN H., CHENG K., LU L., ZHENG M., WANG K., HUA S., ZHU C., WANG Y. The variation of chemical characteristics of PM2.5 and PM10 and formation causes during two haze pollution events in urban Beijing, China. Atmospheric Environment, 107, 1, 2015.

5. WANG M., CAO C., Li G., SINGH R.P. Analysis of a severe prolonged regional haze episode in the Yangtze River Delta, China. Atmospheric Environment, 102, 112, 2015.

6. HENGCHONG L., SIYU Y., JUNG Z. Coal-based synthetic natural gas (SNG) for municipal heating in China: analysis of haze pollutants and greenhouse gases (GHGs) emissions. Journal of Cleaner Production, 112, 1350, 2016.

7. ZHANG Y., CAO F. Is it time to tackle $\mathrm{PM}_{2.5}$ air pollutions in China from biomass-burning emissions?. Environmental Pollution, 202, 217, 2015.

8. ZHOU S., YANG L., GAO R., WANG X., GAO X., NIE W., XU P., ZHANG Q., WANG W. A comparison study of carbonaceous aerosols in a typical North China Plain urban atmosphere: Seasonal variability, sources and implications to haze formation. Atmospheric Environment, 149, 95, 2017.

9. WANG H., ZHU B., Shen L., AN J., YIN Y., KANG H. Number size distribution of aerosols at Mt. Huang and Nanjing in the Yangtze River Delta, China: Effects of air masses and characteristics of new particle formation. Atmospheric Research, 150, 42, 2014.

10. SHEN X.J., SUN J.Y., ZHANG X.Y., ZHANG Y.M., ZHANG L., CHE H.C., MA Q.L., YU X.M., YUE Y., ZHANG Y.W. Characterization of submicron aerosols and effect on visibility during a severe haze-fog episode in Yangtze River Delta, China. Atmospheric Environment, 120, 307, 2015. 
11. HAN S., WU J., ZHANG Y., CAI Z., FENG Y., YAO Q., LI X., LIU Y., ZHAGN M. Characteristics and formation mechanism of a winter haze - fog episode in Tianjin, China. Atmospheric Environment, 98, 323, 2014.

12. PENG Z., WU L. A new perspective on formation of hazefog: the fuzzy cognitive map and its approaches to data mining. Sustainability, 9 (3), 352, 2017.

13. FU H., CHEN J. Formation, features and controlling strategies of severe haze-fog pollutions in China. Science of the Total Environment, 578, 121, 2017.

14. ZHANG Z., GONG D., MAO R., KIM S., XU J., ZHAO $X$., MA Z. Cause and predictability for the severe haze pollution in downtown Beijing in November-December 2015. Science of the Total Environment, 592, 627, 2017.

15. SEVIK H., CETIN M. Effects of water stress on seed germination for select landscape plants. Polish Journal of Environmental Studies, 24 (2), 689, 2015.

16. CETIN M., SEVIK H. Measuring the impact of selected plants on indoor $\mathrm{CO}_{2}$ concentrations. Polish Journal of Environmental Studies, 25 (3), 973, 2016.

17. KUSCU K.S.I., CETIN M., YIGIT N., SAVACI G., SEVIK H. Relationship between enzyme activity (urease-catalase) and utrient element in soil use. Polish Journal of Environmental Studies, 27 (5), 1, 2018.

18. GUNEY K., CETIN M., GUNEY B.K., MELEKOGLU A. The effects of some hormone applications on Lilium martagon L. germination and morpholgical characters. Polish Journal of Environmental Studies, 26 (6), 2533, 2017.

19. CETIN M., ADIGUZEL F., KAYA O., SAHAP A. Mapping of bioclimatic comfort for potential planning using GIS in Aydin. Environment, Development and Sustainability 20 (1), 361, 2018.

20. TURKYILMAZ A., SEVIK H., CETIN M., SALEH A.A.E. Changes in heavy metal accumulation depending on traffic density in some landscape plants. Polish Journal of Environmental Studies, 27 (5), 1, 2018.

21. XIE R., YUAN Y., HUANG J. Different types of environmental regulations and heterogeneous influence on "green" productivity: evidence from China. Ecological Economics, 132, 104, 2017.

22. TANG D., TANG J., XIAO Z., MA T., BATHEL B.J. Environmental regulation efficiency and total factor productivity - effect analysis based on Chinese data from 2003 to 2013. Ecological Indicators, 73, 312, 2017.

23. LI B., WU S. Effects of local and civil environmental regulation on green total factor productivity in China: a spatial Durbin econometric analysis. Journal of Cleaner Production, 153, 342, 2017.

24. MU Z., BU S., XUE B. Environmental legislation in China: achievements, challenges and trends. Sustainability, 6 (12), 8967, 2014.

25. ZHAO X., ZHAO Y., ZENG S., ZHANG S. Corporate behavior and competitiveness: impact of environmental regulation on Chinese firms. Journal of Cleaner Production, 86, 311, 2015.
26. KEARSLEY A., RIDDEL M. A further inquiry into the Pollution Haven Hypothesis and the Environmental Kuznets Curve. Ecological Economics, 69 (4), 905, 2010.

27. KONISKY D.M. Regulatory competition and environmental enforcement: is there a Race to the Bottom? American Journal of Political Science, 51 (4), 853, 2007.

28. LANOIE P., LAURENT-LUCCHETTI J., JOHNSTONE N., AMBEC S. Environmental policy, innovation and performance: new insights on the Porter Hypothesis. Journal of Economics and Management Strategy, 20 (3), 803, 2011.

29. BI G., SONG W., ZHOU P., LIANG L. Does environmental regulation affect energy efficiency in China's thermal power generation? Empirical evidence from a slacks-based DEA model. Energy Policy, 66, 537, 2014.

30. HAO Y., LIU Y., WENG J., GAO Y. Does the Environmental Kuznets Curve for coal consumption in China exist? New evidence from spatial econometric analysis. Energy, 114, 1214, 2016.

31. CHUNG S. Environmental regulation and foreign direct investment: evidence from South Korea. Journal of Development Economics, 108, 222, 2014.

32. CAI X., LU Y., WU M., YU L. Does environmental regulation drive away inbound foreign direct investment? Evidence from a quasi-natural experiment in China. Journal of Development Economics, 123, 73, 2016.

33. RUBASHKINA Y., GALEOTTI M., VERDOLINI E. Environmental regulation and competitiveness: empirical evidence on the Porter Hypothesis from European manufacturing sectors. Energy Policy, 83, 288, 2015.

34. RAMANATHAN R., HE Q., Black A., GHOBADIAN A., GALLEAR D. Environmental regulations, innovation and firm performance: a revisit of the Porter hypothesis. Journal of Cleaner Production, 155, 79, 2017.

35. WANG Y., SHEN N. Environmental regulation and environmental productivity: the case of China. Renewable and Sustainable Energy Reviews, 62, 758, 2016.

36. ANSELIN L. Local indicators of spatial association LISA. Geographical Analysis, 27 (2), 93, 1995.

37. GROSSMAN G.M., KRUEGER A.B. Economic growth and the environment. The Quarterly Journal of Economics, 110 (2), 353, 1995.

38. BAKSI S., BOSE P. Environmental regulation in the presence of an informal sector. University of Winnipeg Department of Economics Working Paper, 3. 2010.

39. ANTWEILER W., COPELAND B.R., TAYLOR M.S. Is free trade good for the environment. American Economic Review, 91 (4), 877, 2001.

40. XIE Y., ZHAO L., XUE J., HU Q., XU X., WANG H. A cooperative reduction model for regional air pollution control in China that considers adverse health effects and pollutant reduction costs. Science of the Total Environment, 573, 458, 2016. 
